\begin{tabular}{|c|c|c|}
\hline \hline & $\begin{array}{c}\text { International Journal of Current Research in } \\
\text { Biosciences and Plant Biology }\end{array}$ \\
\hline EXCELLENT \\
PUBLISHERS
\end{tabular}

\title{
The Role of Rot Fungi in Composting Process of Empty Fruit Bunches of Oil Palm
}

\author{
Sukriming Sapareng ${ }^{1}$, Ambo Ala ${ }^{2}$, Tutik Kuswinanti ${ }^{3}$, Burhanuddin Rasyid ${ }^{4}$ \\ ${ }^{I}$ Post Graduate Program of Hasanuddin University, Makassar, Faculty of Agriculture, Andi Djemma Palopo University, \\ South Sulawesi, Indonesia \\ ${ }^{2}$ Department of Agronomy, Faculty of Agriculture, Hasanuddin University, Makassar, Indonesia \\ ${ }^{3}$ Department of Plant Pests and Diseases, Faculty of Agriculture, Hasanuddin University, Makassar, Indonesia \\ ${ }^{4}$ Departement of Soil Science, Faculty of Agriculture, Hasanuddin University, Makassar, Indonesia
}

*Corresponding author.

\section{Abstract}

Empty Fruit Bunches of Oil Palm cannot be readily decomposed as they are still in complex elemental form, therefore must be degraded first, yet natural degradation processes takes a very long time, hence the use of fungi can accelerate the degradation process by various enzymes they produced. Rot fungi possess the ligninolytic capability i.e., producing enzyme that degrade lignin. The materials used in this study include EFB of oil palm, bran, and dolomite lime. Ingredients were mixed evenly and then inoculated with 3 different rot fungi. Treatment 1: without rot fungi (control), treatment 2: Trichoderma sp., treatment 3: Pleurotus ostreatus, and treatment 4: Tramella sp. Composting process was done on the vessel with dimension of $200 \times$ $100 \times 80 \mathrm{~cm}$. Compost was covered with a tarpaulin, mixed and reversed thoroughly every 2 weeks, and placed under the shade for 12 weeks to accelerate decomposition. The results showed that the inoculation of the rot fungus accelerate the composting process, improve the physical and chemical properties and contribute to the nutrient content of the compost. This study showed that the quality of the compost with different parameters such as temperature, $\mathrm{pH}$ and the ratio $\mathrm{C}$ : $\mathrm{N}$ was good. Temperature was increased in all treatments after three weeks and then decreased gradually until the stage of maturity of compost. The inoculation treatment with Trichoderma sp had better quality than other treatments. $\mathrm{C} / \mathrm{N}$ ratio and $\mathrm{pH}$ of mature compost was 18.68 and 6.1. It was concluded that inoculation of Trichoderma sp is potential for EFB decomposition.
\end{abstract}

\section{Introduction}

Bunches of oil palm empty (EFB) cannot directly decompose because they are still in complex

\section{Article Info}

Accepted: 13 February 2017

Available Online: 06 March 2017

\section{Keywords}

Bio-decomposer

Empty fruit bunches

Ligninolytic fungi

Palm oil

Rot fungi 
produce enzymes that degrade lignin (Goyal et al., 2005). The main components of the oil palm waste are cellulose, hemicellulose and lignin. EFB is composed of cellulose (24-65\%), hemicellulose (21-34\%) and lignin (14-31\%) (Khalil et al., 2007; Kavitha et al., 2013; Chang, 2014).

According to Goyal et al. (2005), the fungus is actively involved in the decomposition of cellulose, hemicellulose and lignin in the organic material. The composting process can be accelerated approximately one month with the inoculation of the cellulosic fungus such as Aspergillus and Trichoderma (Amira et al., 2011; Siddiquee et al., 2016), because of its ability to produce enzymes that degrade cellulose, hemicellulose and lignin (Saili et al., 2014).

Widiastuti et al. (2008) concluded several groups of white rot fungi from the class Basidiomycetes are able to degrade lignin because ligninolytic produce enzymes such as laccase (Lac), lignin peroxidase (Li-P), and Mnperoxidase (Mn-P). De-polymerization of lignin using a variety of fungi often produce low molecular weight aromatic compounds such as guaiacol, coniferil alcohol, $p$-kumarat, ferulic, protokatekuat, $p$-hidroksibenzoat and vanilat (Masai et al., 2007).

Composting is an aerobic process where microorganisms transform organic substrate into carbon dioxide, water, minerals and organic material in controlled conditions, especially moisture and aeration (Bernal et al., 2009; Kala et al., 2009). The main objective is to produce quality humus as much as possible. In the decaying process, physical and chemical changes occurred on the remains of plants and animals become mature organic matter. The response of plants is a key indicator of the quality of the compost.

Shafawati and Siddiquee (2013) stated the level of maturity of the compost can be seen from the primary and secondary criteria. $\mathrm{C} / \mathrm{N}$ ratio, temperature, moisture content, color, and material structures are all secondary criteria; while the main criteria is the growth of plants that are affected by the application of the compost. Compost also improves plant growth at very low cost (Gaind and Nain, 2007). In this study, EFB composted using four potential-rot fungus strain. The purpose of this study was to test the physico-chemical changes such as temperature, $\mathrm{pH}$, and the $\mathrm{C}: \mathrm{N}$ ratio during the composting process inoculated with the four-rot fungi.

\section{Materials and methods}

\section{Procurement of compost materials}

Materials used in this study include EFB, bran, and dolomite lime with the composition of 5: 1: 0.05. EFB derived from palm oil mill Luwu Unit 1, Village Burau Lagego District of Luwu Timur, Indonesia. Bran collected from rice milling factory in the village of Pattimang, Malangke. Dolomite lime was purchased from the farm shop. EFB were chopped small of 5-10 $\mathrm{cm}$ in dimension to accelerate the composting process. Ingredients are mixed evenly and then inoculated with the rot fungus in accordance with the four treatments.

Treatment 1 (K0): No-rot fungus (control), treatment 2 (K1): The fungus Trichoderma sp., Treatment 3 (K2): Fungus Pleurotus sp, and Treatment 4 (K3): Fungus Tramella sp. Rot fungus comes from the collection of Research and Development Centre of Agricultural Biotechnology, University of Hasanuddin. Composting was performed on the vessel measuring $200 \times 100 \times 80$ $\mathrm{cm}(\mathrm{L} \times \mathrm{W} \times \mathrm{H})$ with holes on the sides and bottom of the tub to provide aeration and water discharge during composting. Compost were covered with a tarpaulin and mixed and reversed thoroughly every 2 weeks, and placed in the shade to 12 weeks to accelerate decomposition.

\section{Methods and data analysis}

The temperature is measured every week during the composting process according to the procedures of Erwan et al. (2012). Temperatures were measured at three different places, namely the upper, middle and lower part of the compost using a thermometer. Thermometer inserted for five minutes into the compost. Compost $\mathrm{pH}$ was measured every week during the composting period, approximately $10 \mathrm{~g}$ of compost were put in a $500 \mathrm{~mL}$ beaker and add $50 \mathrm{~mL}$ of sterile water, then shaken for 30 minutes (Jeong and Kim, 2001).

Total Organic Carbon (TOC) was determined in accordance with the method of combustion. One gram of compost is placed in a container and put in a furnace at $350^{\circ} \mathrm{C}$ for one hour. Then the temperature was raised to $550{ }^{\circ} \mathrm{C}$ and left to stand for $4 \mathrm{hrs}$. The remaining ash is weighed, and organic $\mathrm{C}$ was calculated from the weight loss of material during incineration (Kala et al., 2009). The total Kjeldahl Nitrogen (TKN) compost was determined using the Kjeldahl method. 


\section{Results}

\section{Temperature analysis}

Temperature difference during the composting process is illustrated in Fig. 1. Initial temperature of all treatments around was $25^{\circ} \mathrm{C}-36^{\circ} \mathrm{C}$, while the ambient temperature is $30^{\circ} \mathrm{C}$. Compost temperature has increased sharply in the first three weeks, then decrease gradually until the final stages of composting. The highest recorded temperature was $50^{\circ} \mathrm{C}$ for the treatment of $\mathrm{K} 0$ (without fungi), $53^{\circ} \mathrm{C}$ for $\mathrm{K} 1$ (Trichoderma sp.), $55^{\circ} \mathrm{C}$ for $\mathrm{K} 2$ (Pleurotus sp), and $59^{\circ} \mathrm{C}$ for $\mathrm{K} 3$ (Tramella sp.).

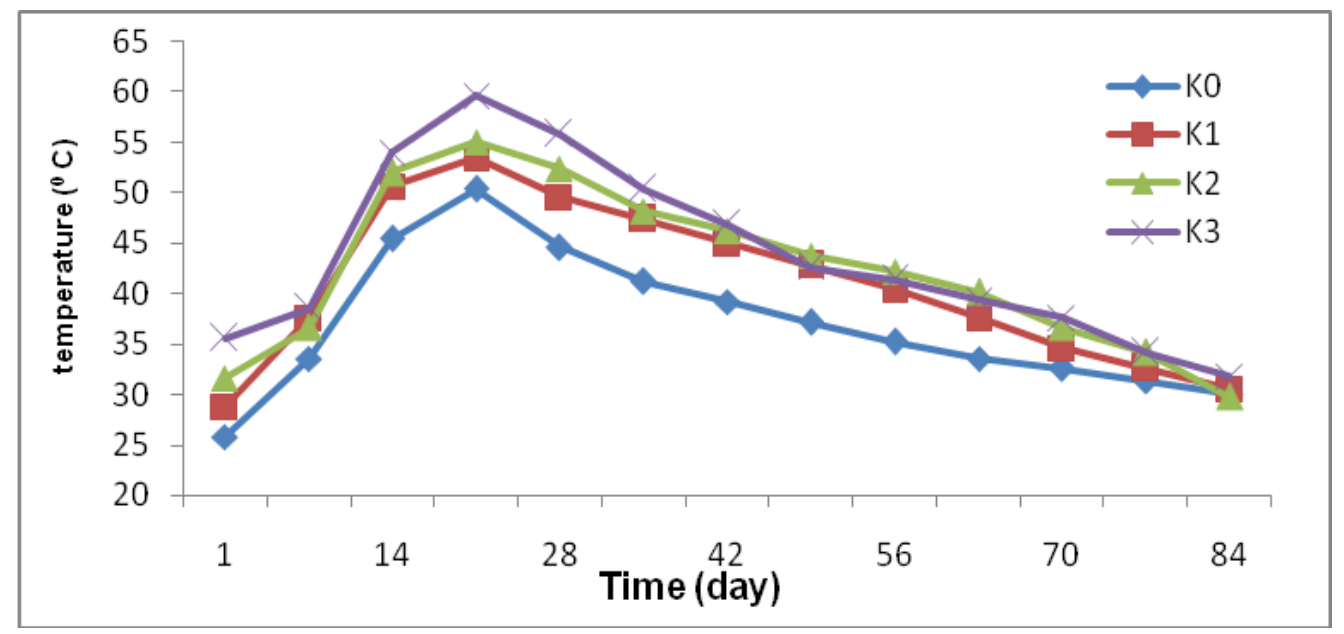

Fig. 1: Changes in the treatment temperature compost EFB K0 (control = No-rot fungus), K1 (Trichoderma sp.), K2 (Pleurotus sp.) and K3 (Tramella sp.).

\section{Changes in pH}

Compost $\mathrm{pH}$ values of all treatments are presented in Fig. 2. The $\mathrm{pH}$ values ranged from 5.4 to 7.8 at the beginning of composting. All treatments have fluctuating $\mathrm{pH}$ values and tend to be more acidic. At the end of the composting process, the $\mathrm{pH}$ value of each treatment $\mathrm{K} 0=5.3, \mathrm{~K} 1=6.1, \mathrm{~K} 2=6.4$, and $\mathrm{K} 3=6.9$.

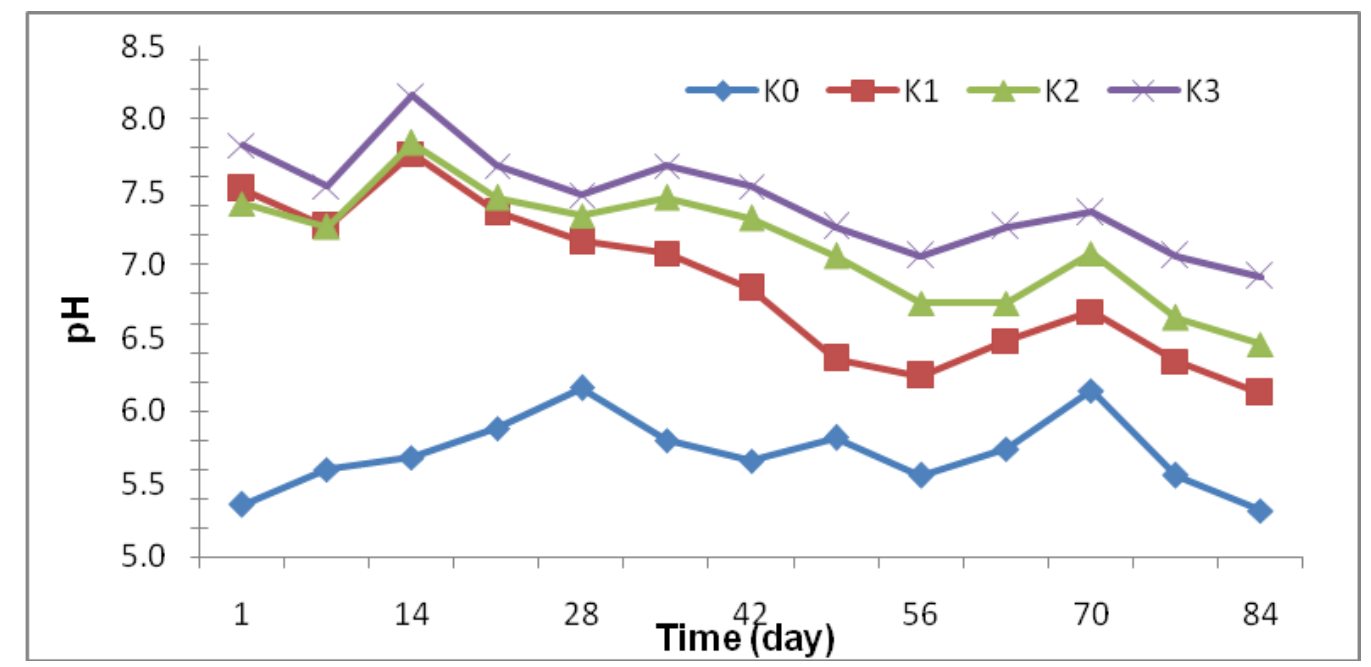

Fig. 2: Changes in pH Compost Treatment EFB on K0 (control = No-rot fungus), K1 (Trichoderma sp), K2 (Pleurotus sp) and K3 (Tramella $\mathrm{sp}$ ).

\section{The ratio of carbon and nitrogen $(\mathrm{C} / \mathrm{N})$}

Changes in $\mathrm{C}: \mathrm{N}$ ratio of EFB compost of all treatments shown in Table 1. The highest ratio of $\mathrm{C}$ : $\mathrm{N}$ obtained by compost without fungus (control) i.e. 34.58 , followed by compost treatment with Tramella sp. (22.52), compost with Pleurotus sp. (21.54) and compost with Trichoderma sp. (18.68) (see Table 1). 
Table 1. Changes in EFB compost C:N ratio during trial.

\begin{tabular}{lllll}
\hline \multirow{2}{*}{ Treatment } & \multicolumn{2}{l}{ Observation time (days) } & $\mathbf{5 6}$ & $\mathbf{8 3}$ \\
\cline { 2 - 5 } & $\mathbf{0}$ & 39.22 & 36.38 & 34.58 \\
K0 (without rot fungus) & 40.24 & 27.38 & 22.09 & 18.68 \\
K1 (Trichoderma sp) & 40.24 & 32.81 & 24.38 & 21.54 \\
K2 (Pleurotus $s p$ ) & 40.24 & 34.34 & 26.68 & 22.52 \\
K3 (Tramella sp) & 40.24 & & \\
\hline
\end{tabular}

\section{Discussion}

\section{Analysis of temperature}

Temperature is one of the most important parameters in the composting process. Rise and fall of temperature during the composting process could be due to the levels of growth, metabolism and types of organisms in the compost (Tiquia and Tam, 2002). The results showed that the values are in the range of thermophilic temperatures ranging from 40 to $65^{\circ} \mathrm{C}$ (Bernal et al., 2009). In this study, all treatments except K0 (without inoculation of the fungus) reaches a temperature of $55^{\circ} \mathrm{C}$ which is required to kill pathogenic microorganisms (Kala et al., 2009). This is due to the metabolic heat as result of rot fungi activity and high cellulose in the compost materials (EFB). Siddiquee et al. (2016), reported that the addition of Trichoderma sp accelerate degradation and improve the physical properties of compost such as water-holding capacity, aeration and texture.

In general, temperatures of all treatments varied. After three weeks, the temperature began to fluctuate, although were still above the ambient temperature. Fluctuating temperatures achieved in the first 21 days of composting for biodegradation of EFB by rot fungi. After eight weeks, the compost temperature approaching the temperature of the environment; biodegradation of EFB almost completed and the process is beginning to stabilize. This occurs because environmental conditions favor the occurrence of biodegradation by rot fungi and affect changes in physical-chemical characteristics of compost (Wei et al., 2016).

\section{Changes in pH}

Changes in $\mathrm{pH}$ due to acid formation during decomposition of EFB are by rot fungi. In the first week, all fungi inoculation treatment showed a small decrease in $\mathrm{pH}$. Thereafter, the $\mathrm{pH}$ in all fungi inoculation treatment increased in the second week. The increase was caused by the decomposition of organic matter, degradation of acid compounds, such as carboxylic and phenolic, and mineralization of organic compounds such as proteins, amino acids, ammonia and peptides (Wong et al., 2001; Xu et al., 2006; Isaac et al., 2014; Wei et al., 2016).

The $\mathrm{pH}$ of compost at the end of composting is more acidic than the initial composting. This is due to nitrification which lowers the $\mathrm{pH}$ of the compost. $\mathrm{pH}$ decreased significantly when the compost is mixed with T. reesei (Gaind and Nain, 2007) and Trichoderma sp. (Siddiquee et al., 2016). The optimum $\mathrm{pH}$ for compost is 6.5-8.0 (Said-Pullicino et al., 2007). During the composting process, organic matter is digested by microorganisms that cause a decrease in the $\mathrm{pH}$ value in the first week. After that, the $\mathrm{pH}$ value increases significantly at the stage of decomposition. The increase was caused by an increase in ammonia (Gajalakshmi and Abbasi, 2008; Petric et al., 2009).

\section{The ratio of carbon and nitrogen $(\mathrm{C} / \mathrm{N})$}

Ratio of $\mathrm{C} / \mathrm{N}$ explains part of $\mathrm{C}$ per unit of $\mathrm{N}$ needed by microorganisms. $\mathrm{C} / \mathrm{N}$ ratio is the main parameter when using compost as fertilizer on soil, because if the value of $\mathrm{C} / \mathrm{N}$ ratio is high, then it can inhibit decomposition and nitrogen availability in the soil. The composting process will lower the $\mathrm{C} / \mathrm{N}$ ratio by converting organic $\mathrm{C}$ to $\mathrm{CO}_{2}$, and the loss of nitrogen in the form of $\mathrm{NH}_{3}$ (Isaac et al., 2014). A decrease in the ratio of $\mathrm{C} / \mathrm{N}$ during the composting process occurred for all treatments (Table 1). $\mathrm{C} / \mathrm{N}$ ratio decreased in all treatments for the mineralization of organic material by microorganisms (Kala et al., 2009). At the end of the experiment, C/N ratio decreased to $34.58,18.68,21.54$ and 22.52 for the treatments, $\mathrm{K} 0, \mathrm{~K} 1, \mathrm{~K} 2$ and $\mathrm{K} 3$ respectively.

$\mathrm{C} / \mathrm{N}$ ratio 17.00 obtained in combination EFB compost, liquid waste and wheat flour that were inoculated with $P$. chrysosporium, T. harzianum and A. niger (Siddiqui et al., 2008). But the $\mathrm{C} / \mathrm{N}$ ratio as high as 59.30 obtained in the olives compost inoculated by Trichoderma harzianum and Phanerochaete chrysosporium (Haddadin et al., 2009). Mature compost has a C / N ratio of less than or equal to 25 (Oreopoulou and Russ 
2007), less than 30 (Chai et al., 2013). Nagasaki et al. (1992) proposed a $\mathrm{C} / \mathrm{N}$ ratio for composting should be in the range of 16 to 21 . The results showed the $\mathrm{C} / \mathrm{N}$ ratio of all treatments except $\mathrm{K} 0$ (without inoculation of the fungus) is within the optimum range $(\leq 25)$.

\section{Conclusions}

This research showed beneficial result that EFB waste could be converted into valuable product within a relatively short time. EFB composting process only takes 28 days and continue to improve with time. The results showed that the inoculation of the rot fungus accelerate the composting process, improve the physical and chemical properties and contribute to the nutrient content of the compost. This study shows the quality of the compost with different parameters such as temperature, $\mathrm{pH}$ and the ratio $\mathrm{C}: \mathrm{N}$. High temperatures in all treatments after three weeks and then decreased gradually until the stage of maturity of compost. The fungus inoculation treatment of Trichoderma $s p$ had better quality than other treatments. $\mathrm{C}: \mathrm{N}$ ratio and $\mathrm{pH}$ of mature compost is 18.68 and 6.1 respectively. It can be concluded that inoculation of Trichoderma sp could be a potential as EFB bio decomposer.

\section{Conflict of interest statement}

Authors declare that they have no conflict of interest.

\section{References}

Amira, R. D., Roshanida, A. R., Rosli, M. I., Siti Fatimah Zahrah, M. F., Mohd Anuar, J., Nazrul Adha, C. M., 2011. Bioconversion of empty fruit bunches (EFB) and palm oil mill effluent (POME) into compost using Trichoderma virens. Afr. J. Biotechnol. 10(81), 18775-18780.

Bernal, M.P., Alburquerque, J.A., Moral, R., 2009. Composting of animal manures and chemical criteria for compost maturity assessment. A review. Bioresour. Technol. 100(22), 5444-5453.

Chai, E.W., H'ng, P. S., Peng, S. H., Wan-Azha, W. M., Chin, K. L., Chow, M. J., Wong, W. Z., 2013. Compost feedstock characteristics and ratio modelling for organic waste materials cocomposting in Malaysia. Environ. Technol. 34(20), 2859-2866.

Chang, S.H., 2014. An overview of empty fruit bunch from oil palm as feedstock for bio-oil production. Biomass Bioener. 62, 174-181.

Erwan, Ismail, M. R., Saud, H. M., Habib, S. H., Siddiquee, S., Kausar, H., 2012. Physical, chemical and biological changes during the composting of oil palm frond. Afr. J. Microbiol. Res. 6(19), 40844089.

Gaind, S., Nain, L., 2007. Chemical and biological properties of wheat soil in response to paddy straw incorporation and its biodegradation by fungal inoculants. Biodegrad. 18(4), 495-503.

Gajalakshmi, S., Abbasi, S.A., 2008. Solid waste management by composting: State of the art. J. Crit. Rev. Environ. Sci. Technol. 38, 311-400.

Goyal, S., Dhull, S.K., Kapoor, K.K., 2005. Chemical and biological changes during composting of different organic wastes and assessment of compost maturity. Bioresour. Technol. 96(14), 1584-1591.

Haddadin, M.S.Y., Haddadin, J., Arabiyat, O. I., Hattar, B., 2009. Biological conversion of olive pomace into compost by using Trichoderma harzianum and Phanerochaete chrysosporium. Bioresour. Technol. 100(20), 4773-4782.

Ishak, N.F., Ahmad, A.L., Ismail, S., 2014. Feasibility of anaerobic co-composting empty fruit bunch with activated sludge from palm oil mill wastes for soil conditioner. J. Physical Sci. 25(1), 77-92.

Jeong, Y.K., Kim, J.S., 2001. A new method for conservation of nitrogen in aerobic composting processes. Bioresour. Technol. 79(2), 129-133.

Kala, D.R., Rosenani, A.B., Fauziah, C.I., Thohirah, L.A., 2009. Composting oil palm wastes and sewage sludge for use in potting media of ornamental plants. Malays. J. Soil Sci. 13(1), 77-91.

Kavitha, B., Rajannan, G., Jothimani, P., 2013. Compost maturity test for empty fruit bunch of palm oil industry solid waste. Sch. Acad. J. Biosci. 1(3), 98101.

Khalil, H.P.S. A., Hanida, S., Kang, C. W., Nik Fuaad, N. A., 2007. Agro-hybrid composite: The effects on mechanical and physical properties of oil palm fiber (EFB)/glass hybrid reinforced polyester composites. J. Reinf. Plastics Composites, 26(2), 203-218.

Masai, E., Katayama, Y., Fukuda, M., 2007. Genetic and biochemical investigations on bacterial catabolic pathways for lignin-derived aromatic compounds. Biosci. Biotechnol. Biochem. 71(1), 1-15.

Nagasaki, T., Chapin, C.J., Gundersen, G.G., 1992. Distribution of detyrosinated microtubules in motile NRK fibroblasts is rapidly altered upon cell. Cell contact: Implications for contact inhibition of 
locomotion. Cell Motil. Cytoskel. 23(1), 45-60.

Oreopoulou, V., Russ, W., 2007. Utilization of Byproducts and Treatment of Waste in the Food Industry. Food \& Nutrition Series, Springer-Verlag US.

Petric, I., Šestan, A., Šestan, I., 2009. Influence of wheat straw addition on composting of poultry manure. Process Saf. Environ. Prot. 87(3), 206-212.

Said-Pullicino, D., Erriquens, F.G., Gigliotti, G., 2007. Changes in the chemical characteristics of waterextractable organic matter during composting and their influence on compost stability and maturity. Bioresour. Technol. 98(9), 1822-1831.

Saili, N.S., Siddiquee, S., Wong, C.M., Ling, V., González, M., Vijay Kumar, S., 2014. Lignocellulolytic activities among Trichoderma isolates from Lahad Datu, Sabah and Deception Island, Antarctic. J. Microb. Biochem. Technol. 6(5), 295302.

Shafawati, S.N., Siddiquee, S., 2013. Composting of oil palm fibres and Trichoderma spp. as the biological control agent: A review. Biodeter. Biodegrad. 85, 243-253.

Siddiquee, S., Shafawati, S.N., Nehar, L., 2016. Effective composting of empty fruit bunches using potential Trichoderma strains. Biotechnol. Rep. 13, $1-7$.

Siddiqui, Y., Meona, S., Ismail, M. R., Ali, A., 2008. Trichoderma-fortified compost extracts for the control of choanephora wet rot in okra production. Crop Prot. 27(3-5), 385-390.

Tiquia, S.M., Tam, N.F.Y., 2002. Characterization and composting of poultry litter in forced- aeration piles. Process Biochem. 37(8), 869-880.

Wei, V. S. J., Bing, C. H., Saptoroand, A., Nandong, J., 2016. Effects of temperature, aeration rate and reaction time on composting of empty fruit bunches of oil-palm. Iran. J. Ener. Environ. 7(2), 156-162.

Widiastuti, H., Suharyanto, Wulaningtyas, A., Sutamihardja., 2008. Activity of ligninolytic enzymes during growth and fruiting body development of white rot fungi Omphalina sp. and Pleurotus ostreatus. Hayati J. Biosci. 15(4), 140-144.

Wong, J.W.C., Mak, K. F., Chan, N. W., Lam, A., Fang, M., Zhou, L. X., Wu, Q. T., Liao, X.D., 2001. Cocomposting of soybean residues and leaves in Hong Kong. Bioresour. Technol. 76(2), 99-106.

Xu, J.M., Tang, C., Chen, Z.L., 2006. The role of plant residues in $\mathrm{pH}$ change of acid soils differing in initial pH. Soil Biol. Biochem. 38(4), 709-719.

\section{How to cite this article:}

Sapareng, S., Ala, A., Kuswinanti, T., Rasyid, B., 2017. The role of rot fungi in composting process of empty fruit bunches of oil palm. Int. J. Curr. Res. Biosci. Plant Biol. 4(3), 17-22.

doi: https://doi.org/10.20546/ijcrbp.2017.403.002 